\title{
Genetic variability among coat protein of Prune dwarf virus variants from different countries and different Prunus species
}

\author{
Elżbieta Kalinowska • Karolina Mroczkowska • \\ Elżbieta Paduch-Cichal • Maria Chodorska
}

Accepted: 1 August 2014 / Published online: 9 August 2014

(C) The Author(s) 2014. This article is published with open access at Springerlink.com

\begin{abstract}
Prune dwarf virus (PDV) isolates have been investigated for genetic diversity. Full-length nucleotide and amino acid sequences of viral coat protein from 23 isolates collected from different stone fruit trees (sour and sweet cherry trees, wild cherry tree, plum tree, almond tree, peach tree) and different countries (Poland, Italy, Germany, USA, Israel) were analysed and compared to 57 others available in GenBank. Comparison of all sequenced virus isolates revealed diversity of 86$100 \%$ at nucleotide level and $79-100 \%$ at amino acid level. The ratio of non-synonymous to synonymous polymorphic sites indicated that purifying selection dominated in case of PDV. However, six codons showed to be under strong positive selection, including the codon located inside the structure involved in RNAbinding activity.
\end{abstract}

Keywords Prune dwarf virus · PDV · Coat protein . Genetic diversity

Stone fruit trees are infected by several viruses, which cause significant economic losses. One of the notable

Electronic supplementary material The online version of this article (doi:10.1007/s10658-014-0502-x) contains supplementary material, which is available to authorized users.

E. Kalinowska $(\bowtie) \cdot$ K. Mroczkowska $\cdot$ E. Paduch-Cichal M. Chodorska

Warsaw University of Life Sciences, Department of Plant Pathology, Nowoursynowska 159, 02-776 Warsaw, Poland e-mail: elzbieta_kalinowska@sggw.pl pathogens is Prune dwarf virus (PDV). PDV is distributed worldwide and infects many Prunus species, including almond, sour- and sweet cherry, peach, apricot, and plum trees (Németh, 1986). Disease symptoms caused by PDV vary from no obvious to serious damages resulting in significant yield and vigour reduction. Disease symptoms can be visible as chlorosis, chlorotic rings and spots on the leaves (sour cherry), stunting, and leaf malformations as well as fruit size reduction (peaches, plums, and prunes) and fruit rain cracking (sweet cherries) (Uyemoto and Scott, 1992; Brunt et al., 1996). Symptoms are correlated with virus isolate, host, and climate (Németh, 1986). PDV is transmitted by grafting as well as through pollen and seeds (Kelley and Cameron, 1986). The virus is also carried inside almond pollen grain (Silva et al., 2003).

PDV belongs to the genus Ilarvirus, family Bromoviridae (King et al., 2012). The virus genome is organized into three plus-stranded RNAs. RNAs 1 and 2 encode conservative proteins involved in viral replication. RNA 3 encodes movement protein (MP) and coat protein $(\mathrm{CP})$, which is expressed via sub-genomic RNA 4 (Bachman et al., 1994).

Despite of differences in serological and biological properties of PDV isolates a molecular characterization of viral coat protein sequences did not reveal a correlation between amino acid composition and host species and/or origin of the viral isolate (Vaškova et al., 2000). Subsequent studies of PDV CP nucleotide sequences revealed higher divergence in almond isolates of PDV than in isolates obtained from other hosts (Fonseca et al., 2005) and indicated presence of four phylogroups: 1. 
Table 1 The author's PDV isolates (bold) and PDV sequences avaible in GenBank

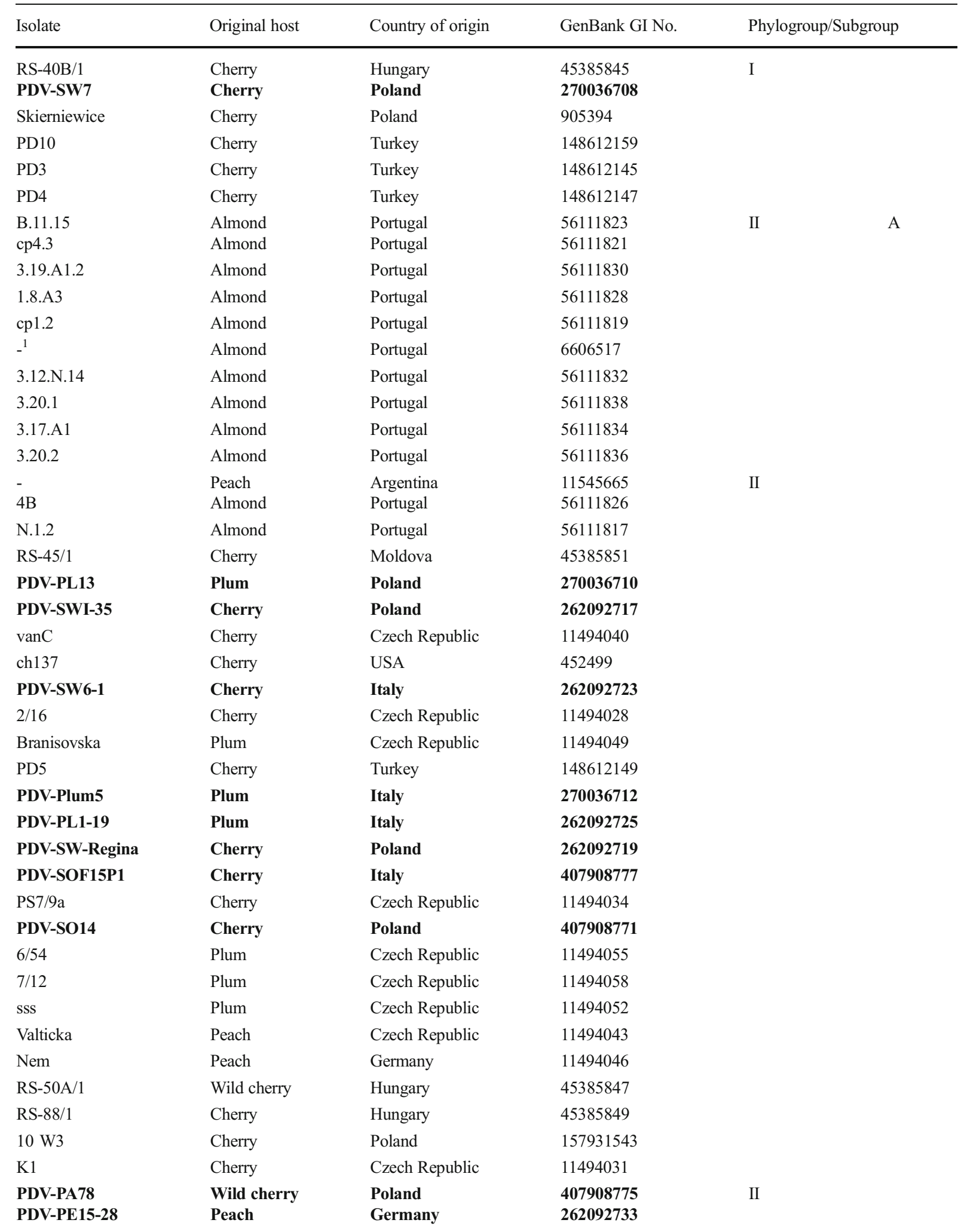


Table 1 (continued)

\begin{tabular}{|c|c|c|c|c|}
\hline Isolate & Original host & Country of origin & GenBank GI No. & Phylogroup/Subgroup \\
\hline $3 \mathrm{~W} 1$ & Cherry & Poland & 157931537 & \\
\hline PDV-PA63 & Wild cherry & Poland & 407908779 & \\
\hline $21 / 1$ & Cherry & Czech Republic & 11494037 & \\
\hline PDVSO40E50 & Cherry & Israel & 262092729 & \\
\hline PDV-SW9-1 & Cherry & USA & 262092721 & \\
\hline PD6 & Cherry & Turkey & 148612151 & \\
\hline PDV-AL2 & Almond & Italy & 262092727 & \\
\hline PDV-SW145W & Wild cherry & Poland & 262092715 & \\
\hline $4 \mathrm{~W} 1$ & Cherry & Poland & 157931539 & \\
\hline $2 \mathrm{C} 3$ & Cherry & Poland & 157931547 & \\
\hline PD2 & Cherry & Turkey & 148612143 & \\
\hline PD9 & Cherry & Turkey & 148612157 & \\
\hline PDV-SWM1 & Cherry & Poland & 407908781 & \\
\hline PD8 & Cherry & Turkey & 148612155 & \\
\hline RS-38/1 & Cherry & Hungary & 45385843 & \\
\hline $\mathrm{MC1}$ & Peach & Brazil & 209944108 & \\
\hline $1 \mathrm{~S} 2$ & Plum & Poland & 157931531 & \\
\hline $5 \mathrm{C} 3$ & Cherry & Poland & 157931549 & \\
\hline $4 \mathrm{M} 2$ & Apricot & Poland & 157931551 & \\
\hline PDV-SOF15P11 & Cherry & Italy & 407908777 & \\
\hline PD7 & Cherry & Turkey & 148612153 & \\
\hline PD1 & Apricot & Turkey & 148612141 & \\
\hline RS-10/4 & Cherry & Hungary & 45331567 & \\
\hline PDV-Almond2 & Almond & Italy & 270036704 & \\
\hline PDV-SOF17P17 & Cherry & Italy & 407908773 & \\
\hline PDV-PE247 & Peach & Poland & 407908783 & \\
\hline DJ1.2 & Wild cherry & China & 343129302 & \\
\hline PDV-SO20SZ1 & Cherry & Poland & 262092711 & \\
\hline PDV-SO20SZ3 & Cherry & Poland & 262092713 & \\
\hline 9 M1 & Apricot & Poland & 157931555 & \\
\hline $5 \mathrm{M} 4$ & Apricot & Poland & 157931553 & \\
\hline $1 \mathrm{C} 3$ & Cherry & Poland & 157931545 & \\
\hline $8 \mathrm{~W} 2$ & Cherry & Poland & 157931541 & \\
\hline $2 \mathrm{~S} 1$ & Plum & Poland & 157931533 & \\
\hline 3B9 & Peach & Poland & 157931535 & \\
\hline
\end{tabular}

${ }^{1}$ Dashes indicate lack of data

mixed 2. cherry I 3. cherry II, and 4. almond (Ulubaș et al., 2009). However, when phylogenetic analysis was based on amino acid sequences, the results indicated the presence of only two groups (Pallas et al., 2012).

Recent studies concerning selective pressure analysis of 36 plant RNA viruses showed that $\mathrm{CP}$ amino acid sequences of PDV and other non-vector borne viruses are more divergent than viruses transmitted by vectors (Chare and Holmes, 2004), although it is still unknown which sites of PDV CP amino acid sequence are under positive selection.

Aim of this work was to compare $23 \mathrm{CP}$ gene sequences of the authors' PDV isolates collections with 57 PDV sequences from GenBank database and to perform 
a phylogenetic analysis of PDV CP genes in order to find motifs that are characteristic for each group/subgroup. The second goal of the study was to calculate the ratio of non-synonymous and synonymous substitutions among the CP gene to determine how selective pressure shapes the amino acid sequence of the PDV population and determine which sites exactly are under positive selective pressure.

The PDV isolates were collected from various geographic regions and different Prunus species (Table 1). Dormant buds from different Prunus species infected with PDV were transferred to Prunus avium (wild cherry) clone F12/1 seedlings using the chip budding technique. To confirm the presence of the virus, each wild cherry clone F12/1 plant was tested by DAS-ELISA using a PDV commercial polyclonal antiserum (Loewe Biochemica $\mathrm{GmbH}$, Germany) according to the procedure by Clark and Adams (1977). In the following examinations, buds and leaves from wild cherry clone F12/1 collection were used as a source of the virus.

Immunocapture reverse transcription polymerase chain reaction (IC-RT-PCR) was conducted according to Malinowski (2005). To amplify the complete sequence of the $\mathrm{CP}$ gene, a primer pair designed by Vaškova et al. (2000) (GTGTAGAAAGAAGAGAAG TCCGACAAG and ATCTAGAAGCAGCATTTCCA ACTACGA) was used for one step RT-PCR (One Tube RT-PCR System; Roche, Germany).

Sequences were analysed with the blastn and blastp programs (http://www.ncbi.nlm.nih.gov/BLAST). Alignments, sequence diversity, and phylogenetic tree were made using MEGA6 (Tamura et al., 2013). The number and ratio of nonsynonymous $(\mathrm{dN})$ and synonymous (dS) substitutions for each codon were estimated on the Datamonkey server (Kosakovsky and Frost,
2005), at http://www.datamonkey.org/, using the random effects likelihood (REL) model, single likelihood ancestor counting (SLAC), and fixed effects likelihood (FEL). Only codons with evidence of selection by all three models were mentioned. Since recombination can have effects on phylogenetic analysis, concatenated sequences of the PDV CP genes were examined for recombination using the SPB (Single Breakpoint Recombination) and GARD (Genetic Algorithm Recombination Detection) programs (Kosakovsky et al., 2006). Phylogenetic examinations were repeated using SPB and GARD trees. For SLAC and FEL, $p$-value was 0.1 and the REL Bayes Factor was 50.

The multiple alignment of PDV isolates revealed sequence identity among 23 studies' sequences ranging from $87-100 \%$ at nucleotide level and $83-100 \%$ at amino acid level. Similar ranges were obtained when sequences were compared with corresponding sequences available in GenBank. The percentage of identity among all nucleotide sequences encoding viral coat protein was from $86-100 \%$. Comparisons of CP amino acid sequences revealed a lower percentage of identity ranging from $79-100 \%$.

Coat proteins of alfamo- and ilarviruses play an important role in the initiation and propagation of infection (Bol, 1999). One arginine located in the $\mathrm{N}$ thermal part of CP is fundamental in RNA-binding activity (Yusibov and Loesch-Fries, 1998). In the case of PDV, the crucial arginine is located at position 14 of the RNAbinding consensus sequence (Q/K/R-P/N-T-X-RS-R/QQ/N/S-W/F-A) (Pallas et al., 2013).

The amino acid alignment of 80 PDV isolates revealed substitution of $\mathrm{R}_{16} / \mathrm{Q}_{16}$ amino acids by $\mathrm{K}_{16}$ in one sequence (GI45331567). Additional replacements

Table 2 Evidence of positive selection among CP of PDV calculated using SLAC, REL and FEL methodologies (dN-dS values). For SLAC and FEL significance level was at 0.1 ( $p$-values), for REL significance level was at 50 (Bayes Factor)

\begin{tabular}{|c|c|c|c|c|c|c|}
\hline \multirow[t]{2}{*}{ Codon } & \multicolumn{2}{|l|}{ SLAC } & \multicolumn{2}{|l|}{ FEL } & \multicolumn{2}{|l|}{ REL } \\
\hline & $\mathrm{dN}-\mathrm{dS}$ & $p$-value & $\mathrm{dN}-\mathrm{dS}$ & $p$-value & $\mathrm{dN}-\mathrm{dS}$ & Bayes Factor \\
\hline 6 & 4.294 & 0.011 & 1.960 & 0.011 & 0.717 & 246.525 \\
\hline 13 & 2.730 & 0.017 & 1.176 & 0.001 & 1.376 & 9823.450 \\
\hline 36 & 2.129 & 0.070 & 0.951 & 0.028 & 1.152 & 208.542 \\
\hline 48 & 3.965 & 0.004 & 1.758 & 0.001 & 1.336 & 12805.400 \\
\hline 97 & 3.276 & 0.019 & 1.369 & 0.017 & 1.100 & 1791.800 \\
\hline 126 & 1.969 & 0.090 & 0.876 & 0.027 & 1.091 & 155.442 \\
\hline
\end{tabular}


were present at $\mathrm{Q}_{17} / \mathrm{N}_{17} / \mathrm{S}_{17}$ positions; in two sequences, these amino acids were changed to $\mathrm{R}_{17}$ (GI407908779) and $\mathrm{G}_{17}$, (GI56111838). In two other sequences (GI262092711, GI262092713), the position $\mathrm{A}_{19}$ was replaced by $\mathrm{S}_{19}$.

A phylogenetic tree of PDV CP amino acid sequences was made using the maximum likelihood method based on the JTT model (Jones et al., 1992). The tree constructed separated all PDV isolates analysed into two clades (Supplementary material - Fig. 1). The first group (phylogroup I) contained all isolates from 'cherry I group' described by Ulubaş et al. (2009). Sequence similarity within the phylogroup I was between 89 $99 \%$ at nucleotide level and $94-99 \%$ at amino acid level. The second group (phylogroup II) included 73 of the 80 analysed isolates and contained one almond subgroup (subgroup A). Sequence similarity within the phylogroup II was between $86-100 \%$ at nucleotide level and $79-100 \%$ at amino acid level. There was no obvious correlation between coat protein sequence and geographic origin of the isolates confirming earlier studies (Vaškova et al., 2000; Fonseca et al., 2005; Ulubaş et al., 2009). Analysis of PDV CP amino acid alignment did not reveal any characteristic motifs in any of the two groups except the presence of $\mathrm{V}$ at position 38 and $\mathrm{S}$ at position 186 in the first cluster.

The CP genes of 80 PDV isolates were initially analysed for recombination using GARD and SBP methods. Although the GARD algorithm did not find recombination events in the analysed data set, the SBP algorithm revealed a recombination point at the 574 nucleotide in the CP PDV alignment using Akaike Information Criterion (AIC), with $100 \%$ of the model average support. It is known that maximum likelihood methods of the codon substitution model used to estimate sites under positive selection may generate false positive results when recombination is not taken into account. For this reason, SBP inferred trees were used in further analysis. The results of SLAC, REL, and FEL estimations revealed that purifying selective pressure dominates in the case of PDV coat protein. All methods estimated strong signals of negative selection for 56 sites, including codons (bold) inside the $\mathrm{Q} / \mathrm{K} / \mathrm{R}-\mathrm{P} / \mathrm{N}-\mathrm{T}$ $\mathrm{X}-\mathrm{RS}-\mathrm{R} / \mathrm{Q}-\mathrm{Q} / \mathrm{N} / \mathrm{S}-\mathrm{W} / \mathrm{F}-\mathrm{A}$ structure. Our result meets with the hypothesis concerning domination of the purifying selection as one of the ways to remove deleterious mutations (García-Arenal et al., 2001). Despite domination of the purifying selective pressure, our estimations revealed that $2.73 \%$ of codons $(6,13,36,48,97$, and
126) were under significant positive selection (Table 2), including codon 13 located at position $\mathrm{X}$ (bold) in the Q/K/R-P/N-T-X-RS-R/Q-Q/N/S-W/F-A context. The mean $\mathrm{dN} / \mathrm{dS}$ value calculated with SLAC method was 0.314 and the mean pairwise diversity was 0.114 . Previous results of selective pressure analysis of PDV CP revealed a mean $\mathrm{dN} / \mathrm{dS}$ of 0.227 and a mean pairwise genetic diversity of 0.032 (Chare and Holmes, 2004). Lower values obtained by Chare and Holmes (2004) may be connected with a smaller dataset available in public databases. Despite differences between estimations, our results meet with the hypothesis that the presence of positive selection in viral populations is connected with the mode of virus transmission and coat proteins of non-vector borne viruses are more tolerant to sequence variability than $\mathrm{CP}$ of vector borne viruses (García-Arenal et al., 2001; Chare and Holmes, 2004). The presence of sites with diversifying selective pressure in viral coat protein may also be connected with changes in host-plant interaction, e.g., gene silencing. Viral gene silencing suppressors may be located in the CP genes (e.g., citrus tristeza closterovirus). An analysis of selective pressure among genes from 17 ssRNA plant viruses revealed $\mathrm{dN} / \mathrm{dS}$ ratios for silencing suppressors, suggesting that diversifying selection may be a viral respones to plant defense (Obbard et al., 2009).

Acknowledgments This work was supported by grant from the Polish Ministry of Science and Higher Education (Grant No. N310 0247 33).

Open Access This article is distributed under the terms of the Creative Commons Attribution License which permits any use, distribution, and reproduction in any medium, provided the original author(s) and the source are credited.

\section{References}

Bachman, E. J., Scott, S. W., Xin, G., et al. (1994). The complete nucleotide sequence of Prune dwarf ilarvirus RNA3: implications for coat protein activation of genome replication in ilarviruses. Virology, 201, 127-13.

Bol, J. F. (1999). Alfalfa mosaic virus and ilarviruses: Involvement of coat protein in multiple steps of the replication cycle. Journal of General Virology, 80, 1089-1102.

Brunt, H. A., Crabtree, K., Dallawitz, M. J., et al. (1996). Viruses of Plants. Wallingford: CAB International. 
Chare, E. R., \& Holmes, E. C. (2004). Selection pressures in the capsid genes of plant RNA viruses reflect mode of transmission. Journal of General Virology, 85, 3149-3157.

Clark, M. F., \& Adams, A. N. (1977). Characteristics of the microplate method of enzyme-linked immunosorbent assay for the detection of plant viruses. Journal of General Virology, 34, 475-483.

Fonseca, F., Neto, J. D., Martins, V., et al. (2005). Genomic variability of Prune dwarf virus as affected by agricultural practice. Archives of Virology, 150, 1607-1619.

García-Arenal, F., Fraile, M., \& Malpica, J. M. (2001). Variability and genetic structure of plant virus populations. Annual Review of Phytopathology, 39, 157-186.

Jones, D. T., Taylor, W. R., \& Thornton, J. M. (1992). The rapid generation of mutation data matrices from protein sequences. Computer Applications in the Biosciences, 8, 275-282.

Kelley, R. D., \& Cameron, H. R. (1986). Location of Prune dwarf and Prunus necrotic ringspot viruses associated with sweet cherry pollen and seed. Phytopathology, 76, 317-322.

King, A. M. Q., Adams, M. J., Carstens, E. B., et al. (2012). Virus taxonomy: Classification and nomenclature of viruses: Ninth report of the international committee on taxonomy of viruses. San Diego: Elsevier Academic Press.

Kosakovsky Pond, S. L., \& Frost, S. D. W. (2005). Datamonkey: Rapid detection of selective pressures on individual sites of codon alignments. Bioinformatics, 21, 2531-2533.

Kosakovsky Pond, S. L., Posada, D., Gravenor, M. B., et al. (2006). Automated phylogenetic detection of recombination using a genetic algorithm. Molecular Biology and Evolution, 23, 1891-1901.

Malinowski, T. (2005). Potential problems with the reliability of PCR based diagnostic methods related to plant viruses sequence variation. Phytopathologia Polonica, 35, 125-139.
Németh, M. (1986). Virus, mycoplasma and rickettsia diseases of fruit trees. Dordrecht: Martinus Nijhoff Publishers.

Obbard, D. J., Gordon, K. H. J., Buck, A. H., et al. (2009). The evolution of RNAi as a defence against viruses and transposable elements. Philosophical Transactions of the Royal Society, B: Biological Sciences, 364, 99-115.

Pallas, V., Aparicio, F., Herranz, M. C., et al. (2012). Ilarviruses of Prunus spp.: A continued concern for fruit trees. Phytopathology, 102, 1108-1120.

Pallas, V., Aparicio, F., Herranz, M. C., et al. (2013). The molecular biology of ilarviruses. Advances in Virus Research, 87, 139-183.

Silva, C., Tereso, S., Nolasco, G., et al. (2003). Cellular location of prune dwarf virus in almond sections by In situ reverse transcription-polymerase chain reaction. Phytopathology, 93, 278-285.

Tamura, K., Stecher, G., Peterson, D., et al. (2013). MEGA6: Molecular evolutionary genetics analysis version 6.0. Molecular Biology and Evolution, 30, 27252729.

Ulubaş, Ç., Ertunç, F., \& Öztrük, A. (2009). Identification and genomic variability of prune dwarf virus variants infecting stone fruit trees in Turkey. Journal of Phytopathology, 157, 298-305.

Uyemoto, J. K., \& Scott, S. W. (1992). Important viruses and grafttransmissible pathogens of stone fruit and nut trees in California and South Carolina. Plant Disease, 76, 5-11.

Vaškova, D., Pertzik, K., \& Špak, J. (2000). Molecular variability of the capsid protein of the prune dwarf virus. European Journal of Plant Pathology, 106, 573-580.

Yusibov, V., \& Loesch-Fries, L. S. (1998). Functional significance of three basic N-terminal amino acids of alfalfa mosaic virus coat protein. Virology, 242, 1-5. 